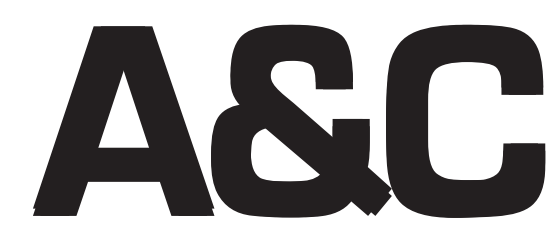

Revista de Direito Administrativo \& Constitucional

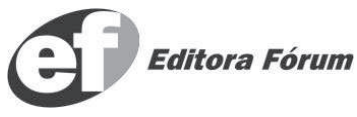

ISSN 1516-3210 


\section{A\&C REVISTA DE DIREITO ADMINISTRATIVO \& CONSTITUCIONAL}

\section{IPDA}

Instituto Paranaense

de Direito Administrativo

Direção Geral

Romeu Felipe Bacellar Filho

Direção Editorial

Paulo Roberto Ferreira Motta

Direção Executiva

Emerson Gabardo

Conselho de Redação

Edgar Chiuratto Guimarães

Adriana da Costa Ricardo Schier

Célio Heitor Guimarães

\section{Conselho Editorial}

Adilson Abreu Dallari (Brasil) Alice Gonzales Borges (Brasil) Antonello Tarzia (Itália)

Carlos Ari Sundfeld (Brasil)

Carlos Ayres Britto (Brasil)

Carlos Delpiazzo (Uruguai)

Cármen Lúcia Antunes Rocha (Brasil)

Celso Antônio Bandeira de Mello

(Brasil)

Clèmerson Merlin Clève (Brasil)

Clovis Beznos (Brasil)

Enrique Silva Cimma (Chile)

Eros Roberto Grau (Brasil)

Fabrício Motta (Brasil)

Guilhermo Andrés Muñoz - in memoriam

(Argentina)

Jaime Rodríguez-Arana Muñoz (Espanha)

Jorge Luís Salomoni - in memoriam
(Argentina)
José Carlos Abraão (Brasil)
José Eduardo Martins Cardoso (Brasil)
José Luís Said (Argentina)
José Mario Serrate Paz (Uruguai)
Juan Pablo Cajarville Peruffo (Uruguai)
Juarez Freitas (Brasil)
Julio Rodolfo Comadira - in memoriam
(Argentina)
Luís Enrique Chase Plate (Paraguai)
Lúcia Valle Figueiredo (Brasil)
Manoel de Oliveira Franco Sobrinho -
in memoriam (Brasil)
Marçal Justen Filho (Brasil)
Marcelo Figueiredo (Brasil)

\author{
Maria Cristina Cesar de Oliveira (Brasil) \\ Nelson Figueiredo (Brasil) \\ Odilon Borges Junior (Brasil) \\ Pascual Caiella (Argentina) \\ Paulo Eduardo Garrido Modesto (Brasil) \\ Paulo Henrique Blasi (Brasil) \\ Paulo Neves de Carvalho - in memoriam \\ (Brasil) \\ Paulo Ricardo Schier (Brasil) \\ Pedro Paulo de Almeida Dutra (Brasil) \\ Regina Maria Macedo Nery Ferrari (Brasil) \\ Rogério Gesta Leal (Brasil) \\ Rolando Pantoja Bauzá (Chile) \\ Sérgio Ferraz (Brasil) \\ Valmir Pontes Filho (Brasil) \\ Weida Zancaner (Brasil) \\ Yara Stropa (Brasil)
}

A246 A\&C Revista de Direito Administrativo \& Constitucional. ano 3, n. 11, jan./mar. 2003. Belo Horizonte: Fórum, 2003.

Trimestral

ano 1, n. 1, 1999 até ano 2, n. 10, 2002 publicada pela Editora Juruá em Curitiba

ISSN 1516-3210

1. Direito Administrativo. 2. Direito Constitucional. I. Fórum.

CDD: 342

CDU: 33.342

(C) 2008 Editora Fórum Ltda.

Todos os direitos reservados. É proibida a reprodução total ou parcial, de qualquer forma ou por qualquer meio eletrônico ou mecânico, inclusive através de processos xerográficos, de fotocópias ou de gravação, sem permissão por escrito do possuidor dos direitos de cópias (Lei nº 9.610, de 19.02.1998).

Editora Fórum Ltda

Editor responsável: Luís Cláudio Rodrigues Ferreira

Av. Afonso Pena, 2770 - 15\%16ªndar - Funcionários

CEP 30130-007 - Belo Horizonte/MG - Brasil

Coordenação editorial: Olga M. A. Sousa

Tel.: 08007043737

Internet: www.editoraforum.com.br

Pesquisa jurídica: Fátima Ribeiro - OAB/MG 74868

Revisora: Lourdes Nascimento

Projeto gráfico e diagramação: Luis Alberto Pimenta

e-mail: editoraforum@editoraforum.com.br

Bibliotecária: Fernanda de Paula Moreira - CRB 2900 - 6a região

Esta publicação está indexada no Ulrich's Periodicals Directory

Os conceitos e opiniões expressas nos trabalhos assinados são de responsabilidade exclusiva de seus autores.

Impressa no Brasil / Printed in Brazil

Distribuída em todo o Território Nacional 


\title{
A competência legislativa municipal para a inovação da linha substitutiva em caso de impedimento ou vacância do Prefeito - Entre autonomia política e democracia popular
}

\author{
Eneida Desiree Salgado \\ Mestre e doutoranda em Direito do Estado pela UFPR. Professora de Direito Constitucional da \\ UFPR.

\section{Emerson Gabardo} \\ Mestre e doutorando em Direito do Estado pela UFPR. Professor de Direito Administrativo da \\ UniBrasil. Diretor-Geral do Instituto de Direito Romeu Felipe Bacellar.
}

\begin{abstract}
Resumo: Trata da questão da autonomia do Município na federação brasileira. Inicia com uma perspectiva histórico-evolutiva. Descreve as características da sistemática constitucional de autonomia, indicando os dispositivos normativos concernentes à matéria. Analisa a questão da competência municipal para a sua auto-organização e, particularmente, para o estabelecimento do regime substitutivo dos chefes do Poder Executivo. Aponta para a existência de limites expressos e imanentes para o exercício desta função políticoorganizacional, tais como o princípio da simetria, o princípio democrático e o da soberania popular. Promove uma refutação à comum proposta legislativa de alocar o Procurador-Geral do Município na linha de substituição e sucessão do Prefeito. Finaliza com uma crítica à condescendência jurisprudencial na matéria, que aceita amplamente a total discricionariedade do legislador municipal.
\end{abstract}

Palavras-chave: Autonomia federativa. Competência municipal. Sucessão do Prefeito. Princípio da simetria. Princípio democrático. Soberania popular.

Sumário: 1 A autonomia do Município na federação brasileira - 2 A competência municipal para sua auto-organização e o regime substitutivo dos chefes do Poder Executivo na Constituição de 1988 - 3 O princípio da simetria como limite negativo inerente ao sistema constitucional - 4 O princípio democrático e a soberania popular como limites expressos ao exercício da competência municipal - Referências

\section{A autonomia do Município na federação brasileira}

A federação brasileira é uma forma de organização "peculiar", pois indica entre os entes federados não apenas a União e os Estados-membros, mas também os Municípios. Todavia, sua particularidade tem sede na própria origem histórica da adoção do regime, na medida em que é conseqüência da desagregação de um Estado unitário, com a elevação das províncias (que detinham autonomia apenas administrativa) a Estados

A\&C R. de Dir. Administrativo \& Constitucional, Belo Horizonte, ano 8, n. 33, p. 219-241, jul./set. 2008 
federados (e, portanto, detentores de autonomia legal, notadamente administrativa, financeira e tributária). Desse modo, diferencia-se das federações que são tomadas usualmente como modelo, como é o caso da norte-americana. Isso em termos eminentemente jurídicos, pois no contexto da realidade fática já se denotava presente uma descentralização político-social desde o Império. Apesar dos esforços normativos para a centralização monárquica, o tamanho do território e a dispersão da população impuseram ao governo central a permanente necessidade de estabelecimento de acordos informais com os poderes regionais. ${ }^{1}$ A "decretação" da federação brasileira, juntamente com a República, em 15 de novembro de 1889, foi uma decorrência natural da realidade política então vigente.

A partir da primeira Constituição republicana, em cujo desenho os Estados federados contam com larga competência normativa e efetiva autonomia, ${ }^{2}$ o Brasil passa ao federalismo "cooperativo" das décadas de 1930, 40 e 50, em que a União concentra parcela considerável das atribuições normativas e tributárias com a finalidade de reduzir as desigualdades regionais e promover o desenvolvimento. Após, decorre o "federalismo de integração" das "constituições" militares, também bastante centralizado na União. A incorporação do Município como ente federado somente acontece na Constituição de 1988, indicando uma nova e complexa tendência de re-descentralização e regionalização (em que pese ainda persistir um forte núcleo de competências políticas para a União).

Do ponto de vista conceitual, a existência de uma federação implica a concessão de autonomia aos entes federados. Todavia, ao ser tratado o "federalismo" é preciso serem identificados dois núcleos de sentido ao termo. Primeiro, como ideologia política, ou seja, um determinado ideário de pretensão normativa a partir do qual se procura governar um Estado a partir de sua divisão territorial em regiões autônomas (ainda que com diferentes noções a respeito do que seria esta autonomia); e, segundo, como forma de organização concreta, ou seja, como o arranjo institucional que determina o "conjunto de leis, normas e práticas que definem como

\footnotetext{
AVELAR; CINTRA (Org.). Sistema político brasileiro: uma introdução, p. 175.

2 Apenas como exemplo da extensão dessa autonomia, ressalte-se que na Constituição do Estado do Rio Grande do Sul de 14 de julho de 1891, o artigo $9^{\circ}$ permitia a reeleição do presidente do Estado, desde que alcançasse $3 / 4$ da preferência do eleitorado, por votação direta. Uma condição de elegibilidade para presidente da província era ser rio-grandense nato e, para a Assembléia dos Representantes, quatro anos de residência no Estado. BRASIL. Legislação da República Federativa do Brasil. A Constituição Federal e as Constituições dos Estados da República do Brasil.
}

A\&C R. de Dir. Administrativo \& Constitucional, Belo Horizonte, ano 8, n. 33, p. 219-241, jul./set. 2008 
um Estado federal é concretamente governado”. Cada Estado configura, portanto, sua peculiar forma federativa. ${ }^{3}$

Em geral, a doutrina nacional aponta que a autonomia federativa compreende dois elementos básicos: a existência de órgãos governamentais próprios (de investidura independente de órgãos federais) e a posse de competências exclusivas. ${ }^{4}$ Alguns autores apontam, ainda, como características da federação, o pacto entre unidades autônomas, a impossibilidade de secessão, a repartição de competências e a união prevista em uma Constituição, além da descentralização político-administrativa, a participação dos Estados no Poder Legislativo federal, a existência de um órgão representativo dos Estados-membros, a possibilidade de intervenção federal, a formação de Estados-membros e a previsão de um órgão de cúpula do Poder Judiciário. ${ }^{5}$

Desse modo, a atribuição de autonomia ao Município não é uma exigência da forma federativa ideológica de Estado. A federação identificase com a existência de uma dupla esfera de poder normativo, com a atribuição de autonomia aos Estados federados e com o reconhecimento da soberania do Estado federal. Foi o sistema concreto instituído pela Constituição de 1988 que optou por incluir o Município como ente federado, atribuindo-lhe competência própria, com reserva explícita em dispositivos constitucionais a ele dirigidos diretamente, ainda que não prevendo sua participação no Poder Legislativo federal, intervenção federal ou competência para apresentar proposta de alteração da Constituição da República.

Prestigiando o modelo teórico e não o concreto, José Afonso da Silva nega ao Município a natureza de ente federado. ${ }^{6}$ Do mesmo modo, autores como Uadi Lammêgo Bulos consideram sua elevação à entidade federativa um exagero do constituinte. ${ }^{7} \mathrm{E}$ um dos argumentos favoráveis a esta percepção é o apontado por Gilmar Ferreira Mendes, que destaca a não participação do ente municipal na vontade federal, além da inexistência de um Poder Judiciário no seu âmbito; razões estas que afastariam o seu status de integrante material da Federação. ${ }^{8}$

Por outro lado, foram tradicionais defensores da configuração do Município como ente federado Hely Lopes Meirelles (e isso já no âmbito

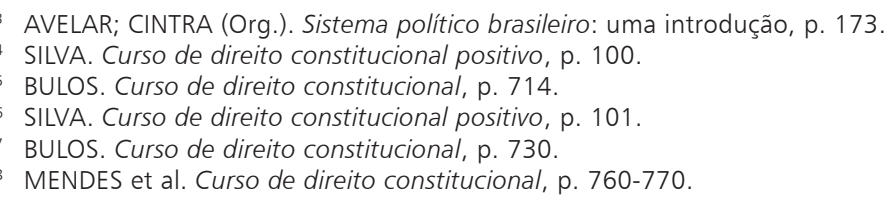

A\&C R. de Dir. Administrativo \& Constitucional, Belo Horizonte, ano 8, n. 33, p. 219-241, jul./set. 2008 
das Constituições anteriores), ${ }^{9}$ Dircêo Torrecillas Ramos (que se apega à questão formal, asseverando que deve ser prestigiada a determinação do texto constitucional), ${ }^{10}$ Celso Ribeiro Bastos (sublinhando a natural autonomia municipal), ${ }^{11}$ e Manoel Gonçalves Ferreira Filho (ressaltando como critério fundamental a existência de um Poder Legislativo próprio). ${ }^{12}$ Mas talvez a melhor defesa do municipalismo a partir de uma perspectiva de combinação entre o Direito material e o Direito formal possa ser encontrada na teoria de Regina Maria Macedo Nery Ferrari. ${ }^{13}$

Todavia, é de pouca relevância a discussão em face da necessária autonomia do Município. Seja ou não um ente federado do ponto de vista material, sua autonomia parece ter sido consolidada formalmente nos textos constitucionais brasileiros. Começou a ser discutida na Constituinte de 1890/1891, conforme anota José de Castro Nunes, ${ }^{14}$ e é uma constante em todas as Cartas constitucionais. É de se notar que o artigo 68 da Constituição de 1891 já dispõe que "os Estados organizar-se-ão de forma que fique assegurada a autonomia dos Municípios em tudo quanto respeite ao seu peculiar interesse". Já a Carta constitucional seguinte, de 1934, traz em seu artigo $7^{\circ}$ os princípios que a Constituição estadual deve observar e elenca entre eles a autonomia do Município, além de tratar das competências do Município no artigo 13, assegurando sua "autonomia em tudo quanto respeite ao seu peculiar interesse", especialmente a eletividade do Prefeito e da Câmara, além de indicar tributos de competência municipal.

A Constituição do Estado Novo repete a expressão sobre a garantia de autonomia municipal em seu artigo 26, mas no artigo seguinte dispõe

\footnotetext{
9 "Já não corresponde à realidade brasileira a afirmativa de Castro Nunes, feita em 1920, de que 'o Município não é peça essencial da Federação'. Não o era na Federação instituída pela Constituição de 1891, plasmada na sua congênere norte-americana, que desconhecia e desconhece até hoje o Município como entidade estatal. Mas é peça essencialíssima da nossa atual Federação, que desde a Constituição de 1946 erigiu o Município brasileiro como entidade estatal de terceiro grau, integrante e necessária ao nosso sistema federativo. A Federação brasileira não dispensa nem prescinde do Município na sua organização constitucional. Segue-se, daí, que o Município brasileiro é entidade político-administrativa de terceiro grau, na ordem descendente da nossa Federação: União - Estados - Municípios". MEIRELLES. Direito municipal brasileiro, p. 44.

10 RAMOS. O Federalismo assimétrico, p. 194.

11 "A autonomia municipal, mesmo do ângulo estritamente jurídico-formal, já deita raízes relativamente profundas no nosso constitucionalismo. Assim sendo, constituía-se uma grossa inadequação ou incoerência do nosso Texto Constitucional o erigir o município em uma entidade autônoma, co-partícipe do exercício da soberania e ao mesmo tempo excluí-la do enunciado descritivo da estrutura federativa brasileira. (...). Se o Brasil adotou e pretende preservar a autonomia político-constitucional do município, não há porque deixar de incluí-lo entre os elementos integrantes da Federação brasileira". BASTOS; MARTINS. Comentários à Constituição do Brasil, v. 1, p. 418-419.

12 Ademais, também é ressaltado pelo autor o federalismo de segundo grau no Brasil da Constituição de 1988, "pois vê os Municípios como plenamente integrantes da estrutura do Estado brasileiro". FERREIRA FILHO. Comentários à Constituição brasileira de 1988, p. 18.

13 FERRARI. Direito municipal, p. 85 et seq.

14 NUNES. Do Estado federado e sua organização municipal, p. 65 et seq.
}

A\&C R. de Dir. Administrativo \& Constitucional, Belo Horizonte, ano 8, n. 33, p. 219-241, jul./set. 2008 
que o Prefeito será livremente nomeado pelo Governador do Estado. De todo modo, o seu artigo 28 elenca as espécies tributárias municipais e o artigo 29 estabelece a possibilidade de agrupamento de Municípios para instalação, exploração e administração de serviços públicos comuns.

O desrespeito à autonomia municipal passa a ser hipótese de intervenção federal nos Estados na Constituição de 1946, segundo o artigo $7^{\circ}$, inciso VII. Já seu artigo 23 elenca duas hipóteses de intervenção estadual nos Municípios - impontualidade no serviço de empréstimo garantido pelo Estado e não pagamento, por dois anos consecutivos, da dívida fundada. A autonomia municipal é assegurada pela eleição do Prefeito e vereadores (embora a Constituição indique a possibilidade de nomeação do Prefeito pelo governador nas capitais, estâncias hidrominerais naturais e determinados em lei federal como relevantes para a segurança nacional) e pela "administração própria, no que concerne ao seu peculiar interesse e, especialmente: a) à decretação e arrecadação dos tributos de sua competência e à aplicação das suas rendas; e b) à organização dos serviços públicos locais" (artigo 28). Finalmente, o artigo 29 da CF/46 mantém a tradicional previsão de tributos de competência municipal.

Na Constituição de 1967 permanece o caso do desrespeito à autonomia municipal como hipótese de intervenção federal nos Estados (artigo 10, inciso VII, alínea “f”). Seu artigo 16 trata da autonomia municipal, assegurada "pela eleição direta de Prefeito, Vice-Prefeito e Vereadores realizada simultaneamente em todo o País, dois anos antes das eleições gerais para Governador, Câmara dos Deputados e Assembléia Legislativa” e pela administração própria, no que concerne ao seu peculiar interesse, especialmente quanto: a) à decretação e arrecadação dos tributos de sua competência e à aplicação de suas rendas, sem prejuízo da obrigatoriedade, de prestar contas e publicar balancetes nos prazos fixados em lei estadual; b) à organização dos serviços públicos locais. Os Prefeitos das capitais e das estâncias hidrominerais, no entanto, são nomeados pelo Governador, com prévia aprovação da Assembléia Legislativa e com prévia aprovação do Presidente da República; do mesmo modo ocorre com "os Prefeitos dos Municípios declarados de interesse da segurança nacional, por lei de iniciativa do Poder Executivo”. As hipóteses de intervenção dos Estados do Município, a ser regulada pela Constituição estadual, resumem-se à impontualidade no pagamento de empréstimo garantido pelo Estado; não pagamento, por dois anos consecutivos, de dívida fundada; e não prestação

A\&C R. de Dir. Administrativo \& Constitucional, Belo Horizonte, ano 8, n. 33, p. 219-241, jul./set. 2008 
de contas pela Administração municipal (parágrafos do artigo 16). O artigo 25 era o que dispunha sobre os tributos municipais.

A Emenda Constitucional de 1969, embora reestruturando a Carta anterior, mantém a ofensa à autonomia municipal como hipótese de intervenção federal nos Estados (artigo 10, inciso VII, alínea “e”). A autonomia municipal continua tratada, porém, no artigo 15, prevendo-se a eleição direta para Prefeito, vice-prefeito e vereadores e "administração própria, no que respeite ao seu peculiar interesse, especialmente quanto: a) à decretação e arrecadação dos tributos de sua competência e à aplicação de suas rendas, sem prejuízo da obrigatoriedade de prestar contas e publicar balancetes nos prazos fixados em lei; e b) à organização dos serviços públicos locais". A Constituição repete as hipóteses de nomeação de Prefeitos pelo Governador, mas as afasta pela Emenda Constitucional $n^{\circ}$ 25/85. O parágrafo terceiro do mesmo artigo 15 elastece o rol de hipóteses de intervenção estadual nos Municípios, prevendo tal medida nos casos de: "a) se verificar impontualidade no pagamento de empréstimo garantido pelo Estado; b) deixar de ser paga, por dois anos consecutivos, dívida fundada; c) não forem prestadas contas devidas, na forma da lei; d) o Tribunal de Justiça do Estado der provimento à representação formulada pelo Chefe do Ministério Público local para assegurar a observância dos princípios indicados na Constituição estadual, bem como para prover à execução de lei ou de ordem ou decisão judiciária, limitando-se o decreto do Governador a suspender o ato impugnado, se essa medida bastar ao restabelecimento da normalidade; e) forem praticados, na administração municipal, atos subversivos ou de corrupção; e f) não tiver havido aplicado, no ensino primário, em cada ano, de vinte por cento, pelo menos, da receita tributária municipal”.

Todavia, apesar da alocação do Município como um ente autônomo na tradição constitucionalista brasileira, faltaram instrumentos legais de concretização. O "amesquinhamento das instituições municipais", segundo palavras de Victor Nunes Leal, decorria em geral da sua "penúria orçamentária, excesso de encargos, redução de suas atribuições autônomas, limitações ao princípio da eletividade de sua administração, intervenção da polícia nos pleitos locais, etc." Todavia, o interessante é que, de forma paradoxal, esta falta de autonomia jurídica (mesmo em um ambiente constitucional favorável) convivia com uma "ampla autonomia extralegal"

A\&C R. de Dir. Administrativo \& Constitucional, Belo Horizonte, ano 8, n. 33, p. 219-241, jul./set. 2008 
dos chefes municipais (tão bem exemplificada com o fenômeno do coronelismo). ${ }^{15}$

De todo modo, esta realidade histórica demonstra claramente que a inclusão do Município na estrutura federativa não foi o resultado de um mero acontecimento tópico na história brasileira, mas sim retratou um fenômeno paulatino, construído jurídica e politicamente a partir de uma situação fática favorável no plano da mentalidade constitutiva do caráter nacional.

\section{A competência municipal para sua auto-organização e o regime substitutivo dos chefes do Poder Executivo na Constituição de 1988}

Na constituinte de 1987/88, a Subcomissão dos Municípios e Regiões adotou propostas apresentadas pelo Instituto Brasileiro de Administração Municipal com a enumeração detalhada das competências municipais. No entanto, o anteprojeto da Comissão de Organização do Estado cujo relator foi José Richa opta por "uma formulação sintética não, porém, menos abrangente, partindo do princípio geral do Direito, segundo o qual o que não for proibido é permitido". O texto colocado em discussão pela Comissão de Sistematização previa competências materiais e legislativas "em assuntos de interesse local predominante" e suplementar à legislação federal e estadual no que coubesse. ${ }^{16}$

Enfim, e após intensos debates e discussões sobre a pertinência e forma de caracterização da natureza e competência do Município, resulta que a Constituição de 1988 inovou substancialmente o federalismo brasileiro, tornando-o tão peculiar que não se encontra similar no Direito comparado. Foi reconhecido o Município como ente federado, inclusive contando a Constituição com disposições dirigidas a ele diretamente. Logo no seu primeiro artigo afirma-se que a República Federativa do Brasil é "formada pela união indissolúvel dos Estados e Municípios e do Distrito Federal” e, no artigo 18, se refere expressamente à autonomia do Município, ao lado dos demais entes federativos. O artigo 23 elenca a competência material comum da União, dos Estados e dos Municípios, e coloca, entre outras, a conservação do patrimônio público, zelar pela guarda da Constituição, das leis e das instituições democráticas.

\footnotetext{
15 LEAL. Coronelismo, enxada e voto: o Município e o regime representativo no Brasil, p. 70. 16 ALMEIDA. Competências na Constituição de 1988, p. 65 et seq.
}

A\&C R. de Dir. Administrativo \& Constitucional, Belo Horizonte, ano 8, n. 33, p. 219-241, jul./set. 2008 
O artigo 29, alterado por quatro emendas (Emenda Constitucional $n^{\circ} 1 / 92$, Emenda Constitucional n ${ }^{\circ} 16 / 97$, Emenda Constitucional n ${ }^{\circ} 19 / 98$ e Emenda Constitucional no 25/2000 - que também insere o artigo 29-A na Constituição), é o que trata, especificamente, da autonomia do Município, estabelecendo os contornos do conteúdo da lei orgânica, assim resumido por Uadi Lammêgo Bulos: organização administrativa do Município; normas de convivência harmônica entre o Executivo e o Legislativo; competências legislativa, comum e suplementar da municipalidade; regras do processo legislativo municipal; disciplina contábil, financeira e orçamentária do Município; assuntos de interesse local, desde que não confrontem com normas constitucionais federais e estaduais; sucessão e substituição do Prefeito e do vice-prefeito. ${ }^{17} \mathrm{O}$ artigo 29-A refere-se à responsabilidade fiscal da Câmara de Vereadores. $\mathrm{O}$ artigo 30 dispõe sobre a competência material e normativa dos Municípios. ${ }^{18} \mathrm{E}$ ainda no capítulo específico, o artigo 31 trata da fiscalização municipal.

A ofensa à autonomia municipal é hipótese de intervenção da União nos Estados (artigo 34, inciso VII, alínea “c”) e o Estado pode intervir no Município se: deixar de ser paga, sem motivo de força maior, por dois anos consecutivos, a dívida fundada; não forem prestadas contas devidas, na forma da lei; não tiver sido aplicado o mínimo exigido da receita municipal na manutenção e desenvolvimento do ensino e nas ações e serviços públicos de saúde; o Tribunal de Justiça der provimento a representação para assegurar a observância de princípios indicados na Constituição Estadual, ou para prover a execução de lei, de ordem ou de decisão judicial. O artigo 156 trata dos impostos municipais, e todo o título sobre a tributação e o orçamento faz referência a tributos que podem ser cobrados pelos

\footnotetext{
17 BULOS. Curso de direito constitucional, p. 732. O autor também afirma, na página 282, que a lei orgânica municipal não é produto do poder constituinte (embora o preâmbulo da Lei Orgânica do Município de Curitiba declare "Nós, representantes do povo, eleitos para a Câmara Municipal, reunidos em Assembléia Municipal Constituinte, com fundamento na Constituição da República Federativa do Brasil (art. 29 e art. 11, parágrafo único, do Ato das Disposições Constitucionais Transitórias), invocando a proteção de Deus, decretamos e promulgamos a seguinte LEI ORGÂNICA DO MUNICÍPIO DE CURITIBA").

18 Art. 30. Compete aos Municípios: I - legislar sobre assuntos de interesse local; II - suplementar a legislação federal e a estadual no que couber; III - instituir e arrecadar os tributos de sua competência, bem como aplicar suas rendas, sem prejuízo da obrigatoriedade de prestar contas e publicar balancetes nos prazos fixados em lei; IV - criar, organizar e suprimir distritos, observada a legislação estadual; V - organizar e prestar, diretamente ou sob regime de concessão ou permissão, os serviços públicos de interesse local, incluído o de transporte coletivo, que tem caráter essencial; VI - manter, com a cooperação técnica e financeira da União e do Estado, programas de educação infantil e de ensino fundamental; (Redação dada pela Emenda Constitucional n 53, de 2006); VII - prestar, com a cooperação técnica e financeira da União e do Estado, serviços de atendimento à saúde da população; VIII - promover, no que couber, adequado ordenamento territorial, mediante planejamento e controle do uso, do parcelamento e da ocupação do solo urbano; IX - promover a proteção do patrimônio histórico-cultural local, observada a legislação e a ação fiscalizadora federal e estadual.
}

A\&C R. de Dir. Administrativo \& Constitucional, Belo Horizonte, ano 8, n. 33, p. 219-241, jul./set. 2008 
Municípios bem como a participação no produto da arrecadação de tributos estaduais e federais. Finalmente, ainda para ilustrar o alcance da autonomia municipal, o artigo 182 refere-se à política de desenvolvimento urbano, executada pelo Poder Público municipal.

Inegável o gradativo incremento da autonomia municipal, sendo a sua Lei Orgânica um importante instrumento de realização do projeto democrático decorrente da Constituição de 1988. Ainda que não se aceite o Município como ente federado, deve-se reconhecer que as cartas constitucionais lhe asseguram um espaço cada vez mais relevante na federação brasileira. E há, indubitavelmente, um espaço normativo destacado atribuído às leis orgânicas municipais (prestigiando-se, inclusive, a democracia participativa). ${ }^{19}$

Um conteúdo necessário da lei orgânica, expressamente referido por Uadi Lammêgo Bulos, é a sucessão (em caso de vacância) e substituição (no caso de impedimento temporário) do Prefeito e do vice-prefeito..$^{20} \mathrm{~A}$ estipulação dos eventuais substitutos ou sucessores não pode, no entanto, afastar-se, no que for possível, dos dispositivos da Constituição Federal e da Constituição estadual. Em que pese exista certa controvérsia com relação à matéria, parece razoável ser exigida uma simetria material em relação às disposições federais e estaduais quanto ao tema, pois se trata de regulamentação de um princípio fundamental da república brasileira: a representação democrática.

A Constituição Federal, em seu artigo 80, determina que em caso de "impedimento do Presidente e do Vice-presidente, ou vacância dos respectivos cargos, serão sucessivamente chamados ao exercício da Presidência da Câmara dos Deputados, o do Senado Federal e o do Supremo Tribunal Federal". E, ainda, no artigo 81 dispõe que "vagando os cargos de Presidente e Vice-presidente da República, far-se-á eleição noventa dias depois de aberta a última vaga”. Finalmente, no parágrafo primeiro deste mesmo dispositivo, estabelece que "ocorrendo a vacância nos últimos dois anos do período presidencial, a eleição para ambos os cargos será feita trinta dias depois da última vaga, pelo Congresso Nacional, na forma da lei”. Em idêntico sentido prevêem, em geral, as Constituições Estaduais. ${ }^{21}$

\footnotetext{
19 Sobre a ligação entre o espaço reservado às Leis Orgânicas municipais e o projeto democrático da Constituição Federal de 1988, ver: SALGADO. Constituição e democracia: tijolo por tijolo em um desenho (quase) lógico: vinte anos de construção do projeto democrático brasileiro, p. 238-239.

20 BULOS. Curso de Direito Constitucional, p. 732.

${ }^{21}$ Caso ilustrativo é o da Constituição do Estado do Paraná, que assim prescreve: Art. 85. Substituirá o Governador, em caso de impedimento, e suceder-lhe-á, no caso de vaga, o Vice-governador do Estado. §1º - em caso de
} 
Parece razoável supor, portanto, que aos Municípios cabe igual competência normativa, que não pode ser avocada pelos Estados-membros, sob pena de uma usurpação inconstitucional de competência. Veja-se que a autonomia do Município para estabelecer normas sobre a sucessão e substituição no Poder Executivo já foi reconhecida expressamente pelo Supremo Tribunal Federal em acórdão lavrado nos seguintes termos:

Não cabe, ao Estado-membro, sob pena de frontal transgressão à autonomia constitucional do Município, disciplinar, ainda que no âmbito da Carta Política estadual, a ordem de vocação das autoridades municipais, quando configuradas situações de vacância ou de impedimento cuja ocorrência justifique a sucessão ou a substituição nos cargos de Prefeito e/ou de Vice-Prefeito do Município. A matéria pertinente à sucessão e à substituição do Prefeito e do Vice-Prefeito inclui-se, por efeito de sua natureza mesma, no domínio normativo da Lei Orgânica promulgada pelo próprio Município. ${ }^{22}$

Desse modo, estabelecida a premissa de que efetivamente o Município possui a prerrogativa funcional de auto-organização nesta matéria (e esta não parece ser uma conclusão difícil de se chegar), cabe analisar se existem limites para o exercício da competência em questão ou o Município seria totalmente livre para estabelecer qualquer conteúdo normativo na regulação local da representação política. De pronto, afirma-se que parece incompatível com a atual sistemática constitucional brasileira a adoção da segunda hipótese.

\section{0 princípio da simetria como limite negativo inerente ao sistema constitucional}

Ainda que exista óbvia competência da Lei Orgânica para dispor sobre a matéria tratada, pois legitima a atuação legislativa da Câmara

impedimento do Vice-governador, ou vacância do seu cargo, serão sucessivamente chamados ao exercício da Governadoria o Presidente da Assembléia Legislativa e o Presidente do Tribunal de Justiça. §2 - Vagando os cargos de Governador e Vice-governador do Estado, far-se-á eleição noventa dias depois de aberta a última vaga. $\S 3^{\circ}$ - Ocorrendo vacância nos últimos dois anos do período governamental, a eleição para ambos os cargos será feita trinta dias depois da última vaga, pela Assembléia Legislativa, na forma da lei.

$22 \mathrm{ADI} \mathrm{n}{ }^{\circ}$ 687/PA, Relator Min. Celso de Mello, julgado em 02.02.95. Ementa: Ação direta de inconstitucionalidade - Autonomia do estado-membro - A constituição do estado-membro como expressão de uma ordem normativa autônoma - Limitações ao poder constituinte decorrente - Imposição, ao Prefeito municipal e respectivos auxiliares, do dever de comparecimento, perante a câmara de vereadores, sob pena de configuração de crime de responsabilidade - Prescrição normativa emanada do legislador constituinte estadual - Falta de competência do estado-membro para legislar sobre crimes de responsabilidade - Ofensa à autonomia municipal - Transgressão ao princípio da separação de poderes - Competência da Câmara Municipal para processar e julgar o Prefeito nos ilícitos político-administrativos - Organização municipal - Esfera mínima de ingerência normativa do estadomembro autorizada pela constituição da república - Exigência de os tribunais de contas encaminharem relatórios trimestrais de suas atividades ao poder legislativo - Plena adequação ao modelo federal consagrado no art. 71, $\S 4^{\circ}$, da constituição da república - Ação direta julgada parcialmente procedente.

A\&C R. de Dir. Administrativo \& Constitucional, Belo Horizonte, ano 8, n. 33, p. 219-241, jul./set. 2008 
Municipal para regular o processo de substituição ou sucessão do Prefeito nos casos de impedimento ou vacância, deve-se reconhecer a existência de limites expressos e imanentes à regulamentação proposta. Pois se é certo que a matéria é de competência local, também não se pode esquecer que seu exercício deve ser exercido nos limites impostos pelas Constituições Federal e Estadual, observando-se, no que for possível, seu regime organizatório. Nesse sentido, explica com precisão o professor José Joaquim Gomes Canotilho:

As normas de criação de órgãos são também (ou são acompanhadas) de normas de competência. Logicamente, a constituição cria, de forma directa, certos órgãos com certas competências. O exercício das competências constitucionalmente normadas deriva directamente da constituição, afirmando-se contra quaisquer leis concretizadoras dessas competências de forma incompatível com o disposto nas normas organizatórias da lei constitucional. ${ }^{23}$

Particularmente, a tratativa municipal de substituição ou sucessão do chefe do Poder Executivo, mais do que regras de mera imitação, constituem normas de reprodução obrigatória situadas no campo do que Raul Machado Horta denomina "campo de preordenação". Sobre a distinção entre regras de imitação e de reprodução, vale a pena mencionar a doutrina do prestigiado constitucionalista mineiro:

\begin{abstract}
A norma de reprodução não é, para os fins da autonomia do Estado-membro, simples normas de imitação, freqüentemente encontrada na elaboração constitucional. As normas de imitação exprimem a cópia de técnicas ou de institutos, por influência de sugestão exercida pelo modelo superior. As normas de reprodução decorrem do caráter compulsório da norma constitucional superior, enquanto a norma de imitação traduz a adesão voluntária do constituinte a uma determinada disposição constitucional. ${ }^{24}$
\end{abstract}

A identificação do regramento sucessório não como normas de mera imitação, mas sim regras de clara reprodução obrigatória decorre da intenção constitucional de alocação do Município como ente federativo. Desse modo, uma interpretação constitucional conformadora irá exigir o respeito à simetria orgânica na constituição de todos os aspectos da normatização municipal que se reportem à representação democrática. $\mathrm{Ou}$ seja, pelo Princípio da Simetria não é admissível se imaginar um grande

\footnotetext{
${ }^{23}$ CANOTILHO. Direito constitucional e teoria da Constituição, p. 1143.

24 HORTA. Estudos de direito constitucional, 78 p.
}

A\&C R. de Dir. Administrativo \& Constitucional, Belo Horizonte, ano 8, n. 33, p. 219-241, jul./set. 2008 
descompasso entre as regras vigentes para a União e para os Estados e aquela existente para os Municípios (mesmo considerando-se a peculiaridade de não possuírem Poder Judiciário local). Sobre este assunto, muito bem esclarecem Luiz Alberto David Araújo e Vidal Serrano Nunes Júnior ao proporem que "o princípio da simetria, segundo consolidada formulação jurisprudencial, determina que os princípios magnos e os padrões estruturantes do Estado, segundo a disciplina da Constituição Federal, sejam tanto quanto possível, objeto de reprodução simétrica nos textos das Constituições estaduais". ${ }^{25}$

Observe-se que o respeito ao Princípio da Simetria não exige a total igualdade normativa, ou seja, mera repetição de texto. Ao contrário, implica uma reprodução da "sistemática", ou mesmo, da "racionalidade" normativa, com vista à garantia da harmonia do sistema. Isso ocorre, pois não se pode ignorar a situação jurídica específica da entidade de menor alcance.

Do ponto de vista prático, a experiência legislativa brasileira aponta que, na maioria dos Municípios, as suas respectivas leis orgânicas estabelecem, em perfeita simetria com a normativa constitucional federal (e estadual) que o vice-prefeito deve suceder o Prefeito em caso de vacância e substituí-lo em caso de impedimento. Todavia, a adoção da possibilidade da reeleição do chefe do Poder Executivo e de seu vice por um período subseqüente provoca uma tendência de alteração nos textos legais, no sentido de ser evitada eventual incompatibilidade do vice-prefeito para disputar a reeleição. ${ }^{26}$ Além disso, o exercício da chefia do Poder Executivo nos seis meses anteriores à eleição atrai a inelegibilidade do parágrafo $7^{\circ}$ do artigo 14 da Constituição para os cônjuges e os parentes até segundo grau do Prefeito em exercício e a incompatibilidade do substituto ou sucessor para disputar outros cargos. E como não há Poder Judiciário local, resta dúvida sobre quem assumiria a Prefeitura, considerando a habitual candidatura dos vereadores para novo mandato (o que os impede de assumir a Prefeitura no período de seis meses anteriores ao pleito).

Em razão desta situação de aparente lacuna no processo de substituição político-representativa, uma alternativa tem sido defendida e aprovada em alguns Municípios: em caso de impedimento do Vice-Prefeito ou de vacância do cargo, serão chamados ao exercício, respectivamente, o

\footnotetext{
25 ARAUJO; NUNES JÚNIOR. Curso de direito constitucional, p. 14 (grifo nosso).

${ }^{26}$ A adoção da reeleição pelo texto constitucional através da Emenda $n^{\circ} 16 / 97$, em total dissonância com a história republicana brasileira e em circunstâncias ainda obscuras, traz uma série de desafios para o Direito eleitoral e para o Direito administrativo.
}

A\&C R. de Dir. Administrativo \& Constitucional, Belo Horizonte, ano 8, n. 33, p. 219-241, jul./set. 2008 
Presidente, o $1^{\circ}$ Vice-Presidente e o $2^{\circ}$ Vice-Presidente da Câmara Municipal (o que não foge da regra tradicional), e, no caso de impedimento destes, o Procurador-Geral do Município (o que implica forte inovação jurídico-política). ${ }^{27}$ Aliás, na realidade, mais do que uma grande novidade inclusa no ordenamento positivo, tal solução configura evidente inconstitucionalidade material, em face de abuso de competência política e de absoluto desrespeito ao princípio da simetria.

Embora o Município não contemple parcela da estrutura do Poder Judiciário em sua esfera de descentralização política, a sistemática legal e constitucional brasileira já possui resposta adequada ao suprimento da lacuna legislativa, sem que seja necessário o rompimento com o princípio da simetria material, com o princípio da representação democrática ou com o princípio da soberania popular. As próprias leis orgânicas municipais, em geral, estabelecem na sua redação originária que em caso de impedimento do vice-prefeito ou de vacância do cargo, será chamado ao exercício o Presidente da Câmara Municipal, e, vagando os cargos de Prefeito e vice-prefeito, deve proceder-se a nova eleição, de acordo com lei específica, em determinado período posterior à abertura da última vaga, devendo os eleitos completar o período de seus antecessores, exceto se a vacância ocorrer no último ano do mandato (ou nos dois últimos). Regra esta em clara simetria com a sistemática constitucional.

Mas por certo resta ainda o problema de saber quem ocupará o cargo provisoriamente, no caso de não poderem os membros da Mesa da Câmara assumirem o mandato por força do período pré-eleitoral. Veja-se que a lei não estabelece a necessidade de eleições no caso de vacância no último ano do mandato, possibilitando, assim, que o substituto acabe por concluir o período de governo efetivamente como governante, sem a necessidade de novas eleições. Tal fato, por si só, já relativiza a adequada atribuição democrática de poderes ao Chefe do Executivo como efetivo representante dos Poderes instituídos na federação brasileira. Contudo, o prejuízo democrático acaba por se tornar realmente insustentável quando se vislumbra a hipótese de este "governante provisório" (que poderá cumprir cerca de um quarto do mandato de Chefe do Poder Executivo municipal) ser um mero funcionário provido para cargo em comissão demissível ad nutum.

Esta fórmula alternativa que vem sendo criada pelo legislador municipal, muito além de significar um correto exercício autônomo de

${ }^{27}$ Este é o caso das novas leis orgânicas dos municípios de Porto Alegre - RS, Santa Maria - RS e Curitiba - PR.

A\&C R. de Dir. Administrativo \& Constitucional, Belo Horizonte, ano 8, n. 33, p. 219-241, jul./set. 2008 
competência do Município, acaba por afastar-se totalmente do modelo constitucional federal e estadual. Há, portanto, claro abuso de competência política, com evidente afronta ao princípio da simetria. O modelo constitucional brasileiro impõe que, nos casos de vacância ou impedimento, a linha de substituição contemple, sempre, detentores de cargos inerentes aos Poderes da República: Legislativo, Executivo e Judiciário. Ademais, mesmo no caso desta regular substituição, exige que sejam feitas eleições rapidamente no caso de vacância; isso ocorre para que se evite ao máximo o exercício ilegítimo do poder político pelo agente substituto. As novas leis orgânicas, na recente forma que vem sendo adotada (e com beneplácito do Judiciário), acabam por contrariar totalmente este modelo, negando a simetria constitucional da Federação e implicando uma recusa à prevalência do critério democrático de escolha dos governantes.

Deve-se ressaltar que em nível federal já existe legislação dispondo da matéria e regulamentando os dispositivos constitucionais. A Lei n ${ }^{\circ} 1.395$ / 51 foi recepcionada pela Constituição de 1988 e estabelece os procedimentos para a eleição indireta de novo Chefe de Estado no caso de vacância nos dois últimos anos do mandato. Assim resguarda-se a representatividade popular. Destaca-se, ainda, que esta lei está prestes a ser alterada de maneira a contemplar também os casos de vacância dos cargos no Legislativo municipal. Bem mais abrangente que a Lei $\mathrm{n}^{\mathrm{O}} 1.395 / 51$, o Projeto de Lei $n^{\circ} 1.292-\mathrm{A} / 99$ estabelece regras para as eleições diretas $\left(\operatorname{artigo} 2^{\circ}\right.$ ) e indiretas na vacância dos cargos de Presidente e Vice-Presidente (artigos $3^{\circ}$ e $4^{\circ}$ ), bem como normas para Governador e Vice-Governador e, ainda, Prefeito e Vice-Prefeito, nos seguintes termos:

Art. $5^{\circ}$ - Vagando os cargos de Governador e Vice-Governador, nos Estados, e de Prefeito e Vice-Prefeito nos Municípios, far-se-á eleição para ambos os cargos: I - noventa dias depois de aberta a última vaga, se a vacância ocorrer nos dois primeiros anos do mandato, observado o disposto no artigo $2^{\circ}$ desta lei;

II - trinta dias depois de aberta a última vaga, se a vacância ocorrer nos dois últimos anos do mandato, pela Assembléia Legislativa, nos Estados e pela Câmara de Vereadores, nos Municípios.

$\S 1^{\circ}$ - O Tribunal Regional Eleitoral estabelecerá os prazos e as normas para a eleição tratada no inciso I, deste artigo, no prazo máximo de sete dias, contado a partir da abertura da última vaga. ${ }^{28}$

\footnotetext{
28 Projeto apresentado pelo Deputado Nicias Ribeiro e pronto para pauta em Plenário.
}

A\&C R. de Dir. Administrativo \& Constitucional, Belo Horizonte, ano 8, n. 33, p. 219-241, jul./set. 2008 
Ainda que por certo seja discutível a constitucionalidade do projeto de lei em questão, o fato é que ele apenas extrai o óbvio sentido constitucional, retratando regras gerais em perfeita sintonia com a sistemática do regime representativo da democracia brasileira. Para respeitar o princípio da simetria, seria necessária a previsão de eleições municipais em trinta dias após a vacância nos últimos dois anos de mandato. Ademais, os substitutos provisórios ou definitivos do Prefeito e Vice-Prefeito devem, necessariamente, ser oriundos de cargo efetivo de um dos Poderes da República: Executivo (Governo — não Administração Pública) ou Legislativo.

Em não possuindo Poder Judiciário, resta ao Município apenas a atribuição da linha substitutiva entre os dois Poderes remanescentes: Executivo e Legislativo. Assim é que parece consistir em única interpretação razoável aquela próxima ao comum texto do Regimento Interno das Câmaras Municipais, que prevêem uma seqüência substitutiva mais ampla dentro do próprio órgão político, seguindo a linha da Mesa, a partir do espectro de vereadores aptos à designação. Na remota hipótese de impossibilidade total da Mesa, e enquanto não houver uma legislação adequada e constitucional que regulamente a situação, parece razoável supor que a substituição deve ser realizada pelo Vereador de idade mais avançada na Casa; esta linha seguirá até o último detentor de mandato eletivo. Assim, restará preservada a autonomia municipal sem serem afrontados os princípios da simetria na organização ou da representação democrática e soberania popular.

\section{0 princípio democrático e a soberania popular como limites expressos ao exercício da competência municipal}

Ainda há outro argumento contrário à substituição do Prefeito pelo Procurador-Geral do Município; e de peso fundamental nos Estados democráticos: o princípio da soberania popular. Em regra, as próprias leis orgânicas estabelecem que a soberania popular será exercida indiretamente pelo Prefeito e pelos Vereadores após sua legitimação pelo sufrágio universal e pelo voto direto e secreto. Esta disposição é consonante com a idéia de que é condição indissociável do exercício de mandatos para a governança e para a legislatura a legitimidade qualificada pelo voto.

Situação assemelhada é a que ocorre quanto aos demais entes federativos, mas que, diferentemente do Município, possuem em sua estrutura outro Poder: o Judiciário, cuja legitimação popular não é estabelecida

A\&C R. de Dir. Administrativo \& Constitucional, Belo Horizonte, ano 8, n. 33, p. 219-241, jul./set. 2008 
pelo sufrágio universal. Os magistrados, no cumprimento de sua função constitucional, também exercitam a soberania popular, porém mediante um processo legitimatório diferenciado de vinculação ao mandato, pois decorrente do concurso público e das promoções por mérito e antigüidade. Desse modo, segundo o modelo federativo estabelecido pela Constituição Federal e seguido obrigatoriamente pelas Constituições Estaduais, é absolutamente exigível que o exercício da soberania popular seja realizado por detentores de cargos efetivos. Mas não quaisquer cargos efetivos e sim aqueles exercentes de função típica de Estado e qualificados por legitimação especial. Ou seja, a soberania popular indireta, para ser exercida, exige dois requisitos fundamentais: a) um determinado processo especial de vinculação ao cargo e b) um conjunto de prerrogativas especiais inerentes ao exercício da função. Ambos os requisitos, cumulados, é que possibilitam a legitimação democrática do exercício das funções típicas inerentes aos Poderes do Estado.

No caso do Poder Executivo e do Poder Legislativo, o processo especial de vinculação ao cargo ocorre a partir da escolha popular mediante sufrágio universal, seguida da diplomação e posse para um mandato fixo. Já no caso do Poder Judiciário, o processo especial é garantido pelo concurso público especial de provas e títulos regulado por lei complementar e composto também pela Ordem dos Advogados do Brasil (ademais, não só o seu ingresso na carreira em cargo efetivo, mas o próprio regime de promoções é regulado na própria Constituição Federal).

O conjunto de prerrogativas especiais do Poder Executivo é estabelecido quando da identificação das atribuições e responsabilidades do Presidente (artigo 84 e seguintes da Constituição Federal). O regime especial do Poder Legislativo é estabelecido pelo artigo 48 e seguintes da mesma Carta Política.

Ainda, no caso dos magistrados, para além do conjunto constitucional de atribuições e responsabilidades (ou seja, do regime especial de exercício do cargo) há um sistema de garantias institucionais que peculiarizam a função estabelecida pelo artigo 95 e seguintes da Carta Magna: inamovibilidade e, principalmente, vitaliciedade. Registre-se que este regime especial de legitimação democrática para o exercício da soberania popular constante na Constituição Federal é de repetição obrigatória nas Constituições Estaduais.

Qualquer outro modelo de preenchimento das funções governamentais, legislativas ou judiciais é vedado pelo ordenamento positivo

A\&C R. de Dir. Administrativo \& Constitucional, Belo Horizonte, ano 8, n. 33, p. 219-241, jul./set. 2008 
nacional e estadual. Desse modo, torna-se totalmente contrária ao "Princípio da Soberania Popular" a permissão para que assuma o cargo de Prefeito um mero detentor de cargo em comissão. E isso por dois motivos fundamentais: a) este cargo não possui a legitimidade democrática inerente aos Poderes do Estado (Executivo e Legislativo - cuja legitimidade decorre do mandato eletivo especialmente protegido); e b) este cargo não possui legitimidade democrática inerente à judicatura típica do Poder Judiciário - cuja legitimidade excepcional justifica-se pela presença de um cargo também especialmente protegido por um regime especial.

O absurdo de ser atribuído ao Procurador-Geral do Município o exercício da Chefia do Poder Executivo, para além da afronta à soberania popular e aos dispositivos constitucionais identificados, decorre da própria natureza do cargo, que pode variar dependendo da legislação local, pois se trata de uma função sem previsão seja na Constituição Federal, seja nas Constituições Estaduais em geral.

Por exemplo, de acordo com a Lei Orgânica de Curitiba (e também na Constituição Estadual do Paraná), ${ }^{29}$ o Procurador-Geral não possui função de governo e nem mesmo de mera gestão, mas sim função administrativa de consultoria e função de representação judicial. Assim dispõe o artigo 74 da LO: "O exercício da representação do Município em juízo dar-se-á mediante a Procuradoria-Geral do Município, órgão ao qual competem as atividades de consultoria do Executivo e a execução da dívida ativa." Esta é uma forma de regulamentação bastante comum nas leis orgânicas da generalidade dos Municípios brasileiros.

Mas o fato é que mesmo na estrutura da União Federal (e no regime orgânico do Estado do Paraná, por exemplo) o Advogado-Geral da União e o Procurador-Geral não exercem (nunca) a soberania popular. Seus cargos são de caráter meramente administrativo, podendo receber, excepcionalmente, algumas competências que, transitoriamente, assemelhariam suas funções aos cargos de Ministro de Estado ou Secretário de Governo, segundo a regulação das Constituições Federal e Estadual.

Entretanto, diversamente da União Federal e do regime comumente existente nos Estados-membros, os legisladores municipais optam, em geral, por reduzir ainda mais o espectro de funções da Procuradoria-Geral.

\footnotetext{
${ }^{29}$ Em que pese no regime da Constituição Estadual do Paraná o Procurador-Geral (artigo 87, parágrafo único) possa receber, excepcional e transitoriamente, competências delegadas de caráter administrativo para a gestão — o que não é permitido no regime da Lei Orgânica de Curitiba.
}

A\&C R. de Dir. Administrativo \& Constitucional, Belo Horizonte, ano 8, n. 33, p. 219-241, jul./set. 2008 
Desse modo, a regra é que, para além de não exercer qualquer função que seja inerente à soberania popular, não exista qualquer previsão nas leis orgânicas para que o Procurador-Geral, mesmo excepcionalmente, assuma funções sequer inerentes aos Secretários de Governo. A natureza da função é, portanto, exclusivamente administrativa de consultoria e judicial de representação do Município.

É preciso que se registre, ainda, que há um conjunto de competências que não podem ser delegadas nem mesmo aos secretários de Estado, sendo privativas do Prefeito e Vice-Prefeito (e se não é possível delegar estas competências aos típicos cargos de direção administrativa, então certamente que não é permitida a delegação a um cargo que só possui competência de consultoria e representação judicial). Não é razoável, portanto, que cargos exclusivamente administrativos passem a assumir funções de governo (sejam administrativas ou legislativas). Até porque o detentor não possui quaisquer garantias inerentes ao cargo.

É exemplo característico a previsão em lei orgânica de um regime de julgamento, pela respectiva Câmara, do Prefeito e secretários nas infrações político-administrativas. E, ainda, a própria sistemática de "destituição de tais cargos após condenação por crime comum ou de responsabilidade. Dificilmente observa-se qualquer disposição, nesta regulamentação, do Procurador-Geral, justamente como uma decorrência do caráter comum e meramente administrativo do cargo, além do que se trata de uma função provida ad nutum..$^{30}$

Fato é que o legislador municipal não possui uma carta branca para concretizar de forma absolutamente discricionária os mecanismos de substituição do representante popular eleito. Há que se considerar, em uma federação, que a Constituição Federal como conjunto de princípios e regras de observância obrigatória estabelece normas que configuram os pontos cardeais do Estado de Direito e da democracia e que, portanto, devem ser levados em consideração quando da atividade normativa dos Estadosmembros e dos Municípios.

Mas infelizmente não parece compreender a extensão do problema o Poder Judiciário brasileiro, que tem sido pouco cauteloso com relação ao assunto. Veja-se que o Tribunal de Justiça do Rio Grande do Sul, por

\footnotetext{
${ }^{30}$ Caso diferente é a situação dos procuradores-gerais dos Estados cujo assento é constitucional e que podem ser processados e julgados pelas Assembléias Legislativas. A título exemplificativo, vejam-se os termos do artigo 54, inciso XII, da Constituição do Estado do Paraná
}

A\&C R. de Dir. Administrativo \& Constitucional, Belo Horizonte, ano 8, n. 33, p. 219-241, jul./set. 2008 
exemplo, não reconheceu a inconstitucionalidade de dispositivo da Lei Orgânica de Porto Alegre que indicou o Procurador-Geral do Município como eventual substituto do chefe do Poder Executivo, em caso de impedimento do Prefeito, do vice-prefeito e do presidente da Câmara de Vereadores. A decisão foi tomada por maioria, gerando oportuno debate e, por sorte, a legislação referia-se apenas à substituição e não à sucessão — ou seja, reconheceu-se válido o exercício do Poder Executivo pelo ProcuradorGeral do Município de maneira temporária, conforme trecho do voto do relator:

Não enseja acolhida, também, o alegado defeito material, sob o enfoque de ferir o princípio da soberania popular, reproduzido no art. $2^{\circ}$ da CE: "A soberania popular será exercida por sufrágio universal e pelo voto direto e secreto, com igual valor para todos...". O raciocínio não é correto, partindo de conceitos abstratos, não se podendo sentir afronta direta ao texto da Carta Riograndense. Na verdade, há clara distinção entre a sucessão do Prefeito, em caso de vaga, através do Vice-Prefeito, e a mera substituição, nos impedimentos, dentro da hierarquia estabelecida: Vice-Prefeito, Presidente da Câmara de Vereadores e o Procurador-Geral do Município. Esse apenas no caso de impedimento dos precedentes, pela ordem, em situação de evidente transitoriedade. Aliás, tal como ocorre, no plano Federal e Estadual, quando chamado a exercer o Executivo, em caráter transitório, o Chefe do Poder Judiciário (Presidentes do STF ou do Tribunal de Justiça). Hipótese em que ninguém imagina falar em desrespeito ao princípio da soberania popular. É o que ocorre na arquitetura de substituição no Município de Porto Alegre, preenchendo um vácuo na administração municipal, chegando-se ao Procurador-Geral, como se poderia também chegar a um Secretário Municipal, também não jungido pelo voto universal, haja vista que mais restrita é a ordem a ser seguida, não concorrendo o judiciário. ${ }^{31}$

Ainda assim, não parece ter acolhido a melhor interpretação o tribunal gaúcho. Não há como se comparar o caso municipal com a possibilidade de substituição do Presidente da República ou do Governador do Estado pelo Presidente do Supremo Tribunal Federal ou do Tribunal de Justiça. Os casos de substituição do chefe do Poder Executivo pelo chefe

\footnotetext{
31 ADI n 70009237090, julgada em 25.10.04, relator Des. Luiz Ari Azambuja Ramos. Ementa: Ação direta de inconstitucionalidade. Município de Porto Alegre. Lei Orgânica (art. 91, §2 ). Substituição eventual do Prefeito municipal. Impedimento na ordem precedente de substituição. Procurador-geral do município. Impossibilidade jurídica do pedido que não se ostenta. Carta estadual incorporando os princípios balizadores da Constituição Federal (art. $8^{\circ}$ ). Inconstitucionalidade inocorrente. Defeito formal inexistente, regular processo legislativo. Interstício de dez dias, entre uma votação e outra, não exigível em caso de emenda à LOM, apenas se impondo observado na formação de sua estrutura originária. Vício material inacolhível. Princípio da soberania popular não desrespeitado. Substituição eventual e transitória do Prefeito, preenchimento de um vácuo administrativo, verificando-se impedimento na ordem sucessória, sem representar afronta ao princípio do voto popular. Ação improcedente.
}

A\&C R. de Dir. Administrativo \& Constitucional, Belo Horizonte, ano 8, n. 33, p. 219-241, jul./set. 2008 
de outro poder constituído (ainda que de legitimidade democrática indireta, como o magistrado), não se iguala de maneira alguma à previsão do exercício do Poder Executivo por um detentor de cargo de confiança, demissível a qualquer momento pelo Prefeito e sem atribuições equivalentes na Lei Orgânica. Ofende-se a soberania popular mesmo em caso de substituição; é tão inconcebível, portanto, quanto o de sucessão.

Igual sorte - ou azar, para o constitucionalismo e para o Estado Democrático de Direito - teve a ação direta de constitucionalidade proposta contra a Lei Orgânica de Santa Maria, que dispõe: "Em caso de impedimento ou vacância dos cargos de Prefeito Municipal e Vice-Prefeito assumirá o Poder Executivo o Presidente da Câmara Municipal. § $1^{\circ}$ - Não sendo possível a assunção do Presidente da Câmara Municipal ao cargo de Prefeito, deverá haver a designação pelo Prefeito, de servidor titular de cargos de primeiro escalão para a função de gestor administrativo do poder Executivo". Neste caso houve parecer da Procuradoria-Geral do Estado pela inconstitucionalidade, em termos juridicamente irretocáveis:

Como se pode observar, a inconstitucionalidade do art. 94 e seus parágrafos decorre da colisão com o art. $80, \S 1^{\circ}$, da Constituição Estadual, referente à substituição do Governador no caso de impedimento deste e de seu vice, na medida em que no caso do Município, a substituição do Chefe do Executivo Municipal não guarda simetria constitucional com o Estado do Rio Grande do Sul, permitindo-se que servidor titular de cargos de primeiro escalão substitua o Prefeito Municipal ou Vice-Prefeito nos casos de impedimento destes ou vacância do cargo. Com efeito, pelo comando do art. $8^{\circ}$ da Constituição Estadual, os princípios estabelecidos na Constituição Federal e na Constituição Estadual devem ser aplicados aos Municípios. O princípio da simetria, que é inerente ao sistema constitucional, impõe que a Lei Orgânica Municipal adote os parâmetros das Constituições Federal e Estadual. É impossível que o servidor público municipal substitua o Prefeito Municipal no caso de impedimento ou vacância. Isso porque tanto a Constituição Federal quanto a Constituição Estadual prevêem que a substituição do Chefe do Executivo se dá na seguinte ordem: Chefe do Legislativo ou Chefe do Judiciário, sucessivamente. Ademais, o dispositivo ora impugnado não define o tempo necessário para a substituição do Prefeito quando por impedimento deste ou vacância do cargo. Dessa forma, afasta-se mais uma vez dos parâmetros constitucionais, ferindo o estabelecido no art. $80, \S 2^{\circ}$, da Constituição Estadual, que estatui em conformidade com o art. $81, \S \S 1^{\circ}$ e $2^{\circ}$, da Constituição Federal. Não há dúvida de que o modelo estatuído na Constituição Federal referente à substituição do Chefe do Executivo deve, necessariamente, ser de observância obrigatória para os Estados e Municípios. Mister referir que a não-observância de tal modelo constitucional, indubitavelmente, ocasiona a violação do princípio da independência e da harmonia entre os Poderes Legislativo e Executivo (art. $2^{\circ}$ da Constituição Federal). $\mathrm{O}$ art. $1^{\circ}$ da Constituição Estadual disciplina a obrigatoriedade de

A\&C R. de Dir. Administrativo \& Constitucional, Belo Horizonte, ano 8, n. 33, p. 219-241, jul./set. 2008 
observância por parte dos Municípios daqueles princípios fundamentais consagrados e reconhecidos pela Constituição Federal, sendo que o art. $8^{\circ}$ do mesmo diploma legal, de forma expressa, determina que o Município, embora dotado de autonomia política, administrativa e financeira, deve observar os princípios estabelecidos na Constituição Federal e na Carta Estadual. (fls. 215 e 216)

Correto o parecer, apenas com a ressalva de que, no caso dos Municípios, não parece possível ser imaginada a hipótese de previsão de alocação de magistrado na linha sucessiva, exatamente pelo evidente motivo que a atribuição de tal competência somente poderia ser realizada por obra do legislador estadual.

De todo modo, desconsiderou totalmente este parecer o Tribunal, que utilizou para fundamentar sua decisão as razões do acórdão anteriormente referido e votou pela constitucionalidade do dispositivo, ainda que reduzido à hipótese de substituição. ${ }^{32}$ Parece que há, nestes casos, uma ponderação equivocada dos princípios que informam a Constituição Federal. Em nome da defesa da autonomia municipal, afasta-se o princípio democrático e a soberania popular como princípios de legitimação do exercício do poder político. Deixa-se, assim, nas mãos do legislador municipal - ou pior, como nos casos analisados, sob a conveniência política do Prefeito - a indicação do seu substituto ou de seu sucessor.

Não pode haver pior ponderação de princípios como aquela que, fundada em uma prevalência da subsidiariedade, refuta o próprio interesse público e ignorando os prejuízos democráticos, opta pela solução pragmática mais conveniente ao governante sob o pretexto de garantia da autonomia política do ente federativo local. Ou seja, prestigia-se a visão mais restrita e formal da "eficiência administrativa" em detrimento da substancial legitimidade exigida pela sistemática constitucional. ${ }^{33}$

\footnotetext{
32 ADI n 70009325200, julgada em 21.02.2005, relator Des. Vasco Della Giustina. Ementa: Santa Maria. Substituição do Prefeito, vice e presidente do legislativo, em face de vacância ou impedimento, na ordem precedente de substituição, por servidor do primeiro escalão. Ausência de vício material. Sendo temporária a substituição e se não tratando de sucessão, inexiste ofensa ao princípio da soberania popular. Não resta, igualmente, ferido o princípio de simetria com a não assunção do representante do poder judiciário, nos moldes federais e estaduais, pois, a par de o mesmo ser agente político, não escolhido pelo sufrágio universal, os municípios não são dotados de um órgão jurisdicional próprio, com evidente perda de paralelismo com as demais esferas governamentais de poder. Está implícita na autonomia dos municípios e no seu interesse local, (art. 30, I carta federal) a escolha de substitutos eventuais de seus governantes, desde que o seja por tempo limitado, a fim de suprir o vácuo administrativo, limitando-se às atividades de mero expediente administrativo do município, pois as competências privativas são indelegáveis. Precedente jurisprudencial em caso análogo. Não tem competência o legislador municipal, todavia, para alterar ou acrescentar hipóteses de inelegibilidade, violando-se o art. $14, \S \S 3^{\circ}$ ao $9^{\circ} \mathrm{da}$ CF, LC 64/90 e art. $8^{\circ}$ da carta estadual. Adin julgada parcialmente procedente.

33 O que foi e é típico da realidade moderna e contemporânea, notadamente de Estados de legitimação simbólica como é o caso do Brasil. Sobre o assunto, ver: GABARDO. Eficiência e legitimidade do Estado, p. 152 et seq.
} 
Mas não tardará para que as conseqüências desta interpretação que vem predominando nas Câmaras legislativas e nos tribunais pátrios produzam seus frutos indesejáveis. Não são poucos os Municípios que, capitaneados pelos seus respectivos Prefeitos, já vêm fazendo estudos jurídicos para a alocação em suas linhas de sucessão do Poder Executivo não só de procuradores, como de secretários municipais, chefes de gabinetes, assessores jurídicos, etc. Em face do princípio geral do Direito de que para o mesmo caso deve ser aplicada a mesma razão jurídica (ubi aedem ratio, ibi aedem dispositio), está aberta a porta para uma forte quebra da prevalência da soberania popular no ambiente municipal. Ademais, facilita-se o descumprimento do princípio da moralidade, na medida em que passa a caber exclusivamente ao Prefeito a escolha de seus substitutos ou sucessores, facilitando-se com isso os indesejáveis casos de clientelismo e corrupção na barganha de cargos eletivos, infelizmente tão comuns na história brasileira.

\section{Referências}

ALMEIDA, Fernanda Dias Menezes de. Competências na Constituição de 1988. São Paulo: Atlas, 2005.

ARAUJO, Luiz Alberto David; NUNES JÚNIOR, Vidal Serrano. Curso de direito constitucional. 10. ed. São Paulo: Saraiva, 2006.

AVELAR, Lúcia; CINTRA, Antônio Octávio (Org.). Sistema político brasileiro: uma introdução. São Paulo: Ed. Unesp, 2004.

BASTOS, Celso Ribeiro; MARTINS, Ives Gandra. Comentários à Constituição do Brasil. São Paulo: Saraiva, 1988. v. 1.

BRASIL. Legislação da República Federativa do Brasil. A Constituição Federal e as Constituições dos Estados da República do Brasil. Pelotas: Porto Alegre: Echenique \& Irmãos Editores, 1895.

BULOS, Uadi Lammêgo. Curso de direito constitucional. São Paulo: Saraiva, 2007.

CANOTILHO, J. J. Gomes. Direito constitucional e teoria da Constituição. 4. ed. Coimbra: Almedina, 2000.

FERRARI, Regina Maria Macedo Nery. Direito municipal. 2. ed. São Paulo: Revista dos Tribunais, 2005.

FERREIRA FILHO, Manoel Gonçalves. Comentários à Constituição brasileira de 1988. São Paulo: Saraiva, 1997.

GABARDO, Emerson. Eficiência e legitimidade do Estado. São Paulo: Manole, 2003.

HORTA, Raul Machado. Estudos de direito constitucional. Belo Horizonte: Del Rey, 1995.

LEAL, Victor Nunes. Coronelismo, enxada e voto: o Município e o regime representativo no Brasil. 3. ed. Rio de Janeiro: Nova Fronteira, 1997.

A\&C R. de Dir. Administrativo \& Constitucional, Belo Horizonte, ano 8, n. 33, p. 219-241, jul./set. 2008 
MEIRELLES, Hely Lopes. Direito municipal brasileiro. 9. ed. São Paulo: Malheiros, 1997.

MENDES, Gilmar Ferreira et al. Curso de direito constitucional. São Paulo: Saraiva, 2007.

NUNES, José de Castro. Do Estado federado e sua organização municipal. Brasília: Câmara dos Deputados, 1982.

RAMOS, Dircêo Torrecillas. O Federalismo assimétrico. Rio de Janeiro: Forense, 2000.

SALGADO, Eneida Desiree. Constituição e democracia: tijolo por tijolo em um desenho (quase) lógico: vinte anos de construção do projeto democrático brasileiro. Belo Horizonte: Fórum, 2007.

SILVA, José Afonso da. Curso de direito constitucional positivo. 30. ed. São Paulo: Malheiros, 2008.

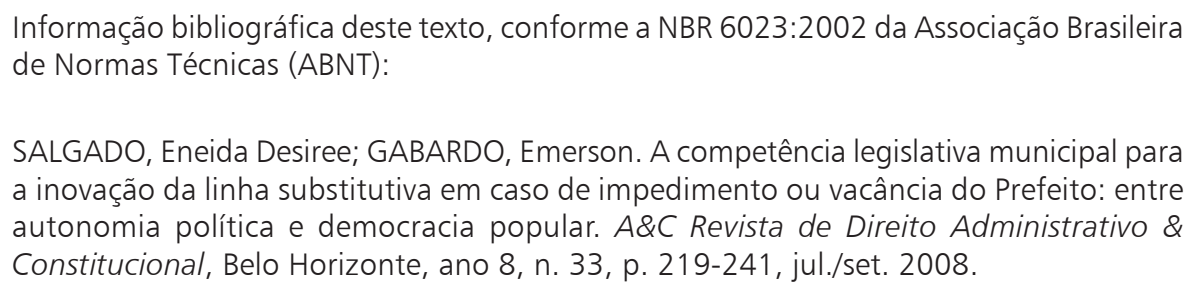

